\section{Nordic Council}

Founded in 1952 as a co-operative link between the parliaments and governments of the Nordic states. The co-operation focuses on Intra-Nordic co-operation, co-operation with Europe/EU/EEA and co-operation with the adjacent areas. The Council consists of 87 elected MPs and the committees meet several times a year, as required. Every year the Nordic Council grants prizes for literature, music, nature and environment.

Members. Denmark (including the Faroe Islands and Greenland), Finland (including Åland), Iceland, Norway, Sweden.

Address: Ved Stranden 18, DK-1061 Copenhagen K, Denmark.

Website: http://www.norden.org

Email: nordisk-rad@norden.org

President: Britt Lundberg (Finland).

\section{Nordic Development Fund (NDF)}

NDF is a multilateral development finance institution established by the five Nordic countries, Denmark, Finland, Iceland, Norway and Sweden. In 1989 NDF began its operations providing soft loans for social and economic development. It entered a new phase in 2009 and changed its focus to grant aid for climate change-related projects. By 2015 NDF had approved 85 projects with a total value of $€ 235.7 \mathrm{~m}$. for climate change projects in 17 countries.

Address: Fabianinkatu 34, PO Box 185, FI-00171 Helsinki, Finland. Website: http://www.ndf.fi

Email: info.ndf@ndf.fi

Managing Director: Pasi Hellman (Finland).

\section{Nordic Investment Bank (NIB)}

The Nordic Investment Bank, which commenced operations in 1976, is a multilateral financial institution owned by Denmark, Estonia, Finland, Iceland, Latvia, Lithuania, Norway and Sweden. It finances public and private projects both within and outside the Nordic area. Priority is given to projects furthering economic co-operation between the member countries or improving the environment. Focal points include the neighbouring areas of the member countries.

Address: Fabianinkatu 34, PO Box 249, FI-00171 Helsinki, Finland. Website: http://www.nib.int

Email: info@nib.int

President: Henrik Normann (Denmark).

\section{Council of the Baltic Sea States}

Established in 1992 in Copenhagen following a conference of ministers of foreign affairs.

Members. Denmark, Estonia, Finland, Germany, Iceland, Latvia, Lithuania, Norway, Poland, Russia, Sweden and the European Commission.

Aims. To promote co-operation in the Baltic Sea region in the field of trade, investment and economic exchanges, combating organized crime, civil security, culture and education, transport and communication, energy and environment, human rights and assistance to democratic institutions.

The Council meets at ministerial level once a year, chaired by rotating foreign ministers; it is the supreme decision-making body. Between annual sessions the Committee of Senior Officials and three working groups meet at regular intervals. In 1999 ministers of energy of the CBSS member states agreed to achieve the goal of creating effective, economically and environmentally sound and more integrated energy systems in the Baltic Sea region. Nine summits at the level of heads of government of CBSS member states and the President of the European Commission have taken place; in 1996 and then every other year since up to and including 2012. The Baltic Sea Region Energy Cooperation (BASREC) is made up of energy ministers from the region and is chaired by the energy minister from the chair country of the CBSS.

Official language: English.

CBSS Secretariat: Strömsborg, PO Box 2010, 10311 Stockholm,

Slussplan 9, Sweden.

Website: http://www.cbss.org

Email: cbss@cbss.org

Director General of the Secretariat: Maira Mora (Latvia).

\section{European Broadcasting Union (EBU)}

Founded in 1950 by western European radio and television broadcasters, the EBU is the world's largest professional association of national broadcasters, with 73 active members in 56 countries of Europe, North Africa and the Middle East, and 33 associate members worldwide. The EBU merged with the OIRT, its counterpart in eastern Europe, in 1993.

The EBU's members operate nearly 2,000 television and radio channels between them, along with numerous online platforms. Together, they reach audiences of more than $1 \mathrm{bn}$. people around the world, broadcasting in more than 120 languages.

The EBU operates the News Exchange, which distributes many thousands of news items a year. Euroradio relays concerts, operas, sports fixtures and major news events via its satellite and IP network. The EBU's Eurovision Operations Department has a permanent network comprising more than 100 satellite channels on eight different satellites, and a fibre network with almost 200 nodes spanning the globe.

Headquarters: Ancienne Route 17A, CH-1218 Grand-Saconnex, Geneva, Switzerland.

Website: http://www.ebu.ch

Email: ebu@ebu.ch

Director-General: Ingrid Deltenre (Netherlands).

\section{Black Sea Economic Cooperation (BSEC)}

Founded in 1992 to promote economic co-operation in the Black Sea region. Priority areas of interest include: trade and economic development; banking and finance; communications; energy; transport; agriculture and agro-industry; healthcare and pharmaceutics; environmental protection; tourism; science and technology; exchange of statistical data and economic information; combating organized crime, illicit trafficking of drugs, weapons and radioactive materials, all acts of terrorism and illegal immigration. 